\title{
Community Participation and Performance of Donor Funded Youth Projects in Korogocho, Nairobi City County, Kenya
}

\author{
Jane Njoki Ndungu', Dr. Janesther Karugu² \\ ${ }^{1}$ Correspondent Author, School of Business, Kenyatta University, Kenya \\ ${ }^{2}$ Lecturer School of Business, Kenyatta University, Kenya
}

\begin{abstract}
World-wide, donor funded projects continue to complement the government's role in the provision of societal developmental needs which include creation of employment opportunities and economic empowerment of local communities. Communities however have not enjoyed these benefits and have remained in poverty and are worse off than before the projects and in this case, the youth in Korogocho have not had their lives changed even after implementation and participation in a project that aimed at empowering them economically by creating sustainable employment opportunities and the donors do not get value for the money put into the project since their objectives are not met. There is however, close and intimate relationship between donor-funded projects success and the community involvement which has not been widely examined with community participation as an integral aspect in the project cycle. The general objective of the study was to examine the influence of community participation on the performance of donor funded youth projects in Korogocho, Nairobi County. The specific objectives of the study were; to examine the influence of community participation in the entire project cycle and the performance of donor funded youth projects in Korogocho i.e. community participation in project identification; community participation in project planning; community participation in project implementation and community participation in monitoring and evaluation on the performance of donor funded youth projects. The study was grounded on the theory of social change, the stakeholder theory and the resource-based view theory. The study utilized a descriptive study targeting 1650 Youth initiative Kenya (YIKE) members and 3 project managers from Oxfam Kenya with a sample size of 165 respondents; 164 YIKE group members being randomly selected and 1 project manager selected from Oxfam Kenya. The study utilized primary and secondary data that was sourced using a semi-structured questionnaire and published reports respectively. The primary data was further be collected using a key informant interview schedule. The collected quantitative data was analyzed using SPSS 23 and Microsoft excel and presented using means, percentages, standard deviation and regression models. The collected qualitative data was analyzed using content analysis and presented in line with the study themes. The findings of the study are anticipated to enhance project implementation and impact. The study was able to obtain a $75 \%$ response rate. The study of the correlation analysis indicated there was strong positive effect of community participation in identification and planning on the project performance while the regression results indicated there is a statistically significant positive effect of community participation on the project performance. The study concludes that donor agencies should strengthen the involvement of the community in the planning, identification and implementation of the project. The study recommends that government agencies should be involved in the process of project identification and execution to foster the project success.
\end{abstract}

Keywords: Community Participation, Project Management, Project Performance, Performance of Donor Funded Youth Projects, Korogocho 
DOI: 10.7176/ijcab.v3iIII.42, URN: nbn:de:0000ijcab.v3iIII.427

\section{Cite this Article:}

Ndungu, J., \& Karugu, J. (2019). Community Participation and Performance of Donor Funded Youth Projects in Korogocho, Nairobi City County, Kenya. International Journal of Current Aspects, 3(III), 227-240. http://journals.ijcab.org/journals/index.php/ijcab/article/view/42

\section{INTRODUCTION}

World-wide, donor funded projects continue to complement the government's role in the provision of societal developmental needs such as access to social economic services such as education, health, water, agriculture, environmental among others (Ramisch \& Verma, 2010). There is however, close and intimate relationship between donor funded projects success and the community involvement; which has not been widely examined (Makori \& Wanyoike, 2015). The World Bank (2008) views participation as a step-wise cavalcade by which stakeholders affect and have control on the initiatives of development and the resources and the decisions which influence them nonetheless Cleaver (2006) desires that participation is taken as faith in development matters as people believe wholeheartedly and don't question. Recently, community participation has evolved as a major model of development and a success basis for local development initiatives. According to Shrimpton (2009), has indicated that community projects are key to enhancing social welfare so as to meet the millennium development projects. These projects have become a driving force for the community's economic growth, creation of employment, and poverty eradication in developing countries. Community development projects are a means through which accelerated economic growth and rapid industrialization can be realized.

According to Ika, Diallo and Thuillier (2012) projects are instrumental tools of promoting welfare and attaining development. However there are challenges associated with donor assistance which include; poor management of the funds, unpredictable donor funding, poor country governance policies (Management Sciences for Health, 2012). Nikkhah and Redzuan (2009) posit that it is hard to achieve community development without involving the members of the community. Participation ensures there is project ownership among the local community. According to Chess and Purcell (2009), who observed that lessons from successful community projects in Western Canada suggest that a sustainable community development must be demand driven. The implementing of community development projects programs provide an enabling environment, and that the community be legally empowered to assume control, ownership and responsibility for the completed projects. They further noted that participation in which the youth get directly involved in community projects ensures that they can take control of their decisions that have direct influence in their lives. They concluded that community involvement in the implementation of community development activities would lead to community empowerment.

In the results of a study in Mali, Brett, Margaret and Tammo (2007) indicated that while implementation of community development projects is a positive step in responding to the needs of the society, the operation process and consultative participatory approaches extension will not necessarily provide sustainable community development and project performance. In Kenya, community participation and decentralized governance was introduced by the Revised Kenyan Constitution 2010 to promote and protect the minority interests and rights, groups that have been marginalized and their subsequent communities. This also encompasses provision of information for making and implementation of regulations, laws and policies. This includes the development proposal approval, budgets and 
projects (County Government Act, 2012). In this way the participation of the local community groups in development initiatives will increasingly contribute to project ownership and sustainable achievements (Ali, 2013). According to Armitage (2010), community participation is the deliberate involvement of community members and the public in the decision making and execution of an intended projects. There is a dire need for extension agents and policy planners to better understand the importance of community participation in the implementation of community development projects. It is also important to recognize that a need exists to better realize the benefits and opportunities that can be achieved through community involvement in the implementation of community development projects (Ali, 2013).

Barasa and Jelagat (2013) indicate that participation in a project includes the involvement of stakeholders in directing and executing the project with a view of attaining the stated goals. Different researchers have conceptualized community participation differently depending on the project being implemented; (Afande, 2013); concluded that the community should be part of the project selection and implementation, Barasa and Jelagat, (2013) indicated that the community should be involved in planning, implementation and project management; Chikati, (2009) is of the view that the community should participate in identification and planning of the project. Khwaja, (2006) is of the view that community participation should not be excessively encouraged however they can be included in advisory committes. From the above its evident that different scholars have conceptualized community participation differently. In the current study community participation was contextualized in the project identifictaion, project planning, project implementation and the project monitoring and evaluation. The project identification process refers to the community involvement in the prioritization and selection of the most appropriate development project. The identification process involves a continuous analysis of the viable projects and the selection of the most ideal projects (Barasa \& Jelagat, 2013). The project planning on the other and is the systematic process that is relied upon in the execution of a project to completion. It involves setting the objectives, deliverables and making scheduled plans (Kumar, 2009).

Project implementation is the various activities that are relied on in carrying out the project as described within the project plan. The execution process allows the community to view the community project plan become a reality (Shrimpton, 2009). The project monitoring on the hand is a continuous process of collecting information of the project to improve the internal and external accountability. Project evaluation refers to the assessment and systematic appraisal of the completed projects against the intended project deliverables (Mulwa, 2008). Project performance is the most important confirmation that project funds have been utilized appropriately to deliver the project goals and targets. However, many projects still fail to achieve and realize expected benefits (Baily et al 2012). Hence, this has led to project delays and cost overrun in some projects. Across the world, project failures have often been reported more than project success. Standish Group (2009) published that in the USA, only 32\% projects succeed, $44 \%$ were challenged and $24 \%$ of projects failed. In Kenya, about $30 \%$ of non-governmental organizations experience failure in their projects (Mathew, 2011).

Pheng and Chuan (2006) posited that the performance of the project is two-faceted; that is one is considered from the angle of the stakeholders and the other from the developer of the project. Project time can be considered as being the duration from the inception of a project to its completion Ngacho, (2013); he points out that there are two main time considerations-; the project time and the actual completion time. Project time failures results from overruns or delays in the execution process (Lensinko, 2015). Shao and Müller (2011) indicated that community satisfaction is a fundamental goal of every project hence it should be considered in evaluation of project performance. This view is supported by Ali and Rahmat (2010), Chan 
and Chan (2004), in their empirical studies which concluded that customer satisfaction is one of the key success metrics of a project. Miles et al. (2008) observed that timely completion, efficiency and effectiveness should be utilized in assessing the project performance. In the current research project performance was measured based on time completion, effectiveness and efficiency in budgetary utilization, project sustainability and the attainment of project objectives. Community participation is essential in a project to ensure the sustainability of the undertaking. The community will be able to actively manage the project as well as contribute to the labour force required to sustain the undertaking (ALNAP, 2009). Involving the members of the public in project execution creates a sense of ownership which is essential for positive project outcome (Kumar, 2009). According to Mansuri and Rao (2004) community participation in projects leads to better designed projects, better targeted benefits, more costeffective projects, more equitable distribution of project benefits and less corruption. Community participation in projects has several benefits.

According to Musa (2012), the participation of the community leads to development of skills for maintenance and sustainability of the project. Okafor (2005) observes that when communities participate in their own projects, the community becomes empowered, and there is greater efficiency, transparency, accountability, enhanced service delivery and generally better project outcomes. He further observes that community participation encourages donor harmonization and can kick start local private contractors and service providers. According to Makori and Wanyoike (2015), there is an increased call for results from donor funded projects in the 21 st century, therefore benefiting countries should view donor support/aid as a business rather than free donations or grants and aim at succeeding in these projects. Strategies at the country level, donor agencies must improve their effectiveness to realize real development effects and eliminate poverty; Afande (2013) notes that there is fresh pressure for a more result based policy from aid opponents, donors and recipients alike which has resulted to a formal process that led to the adoption of the Paris Declaration on Aid Effectiveness in 2005..

Donor funded projects are normally carried out to promote development which could be economic, social or political among less developed communities in developing counties of the world. They aim at alleviating poverty of all forms by undertaking initiatives that will address the systemic constraints among the poor communities (Rondinelli, 2013). Donors, governments and stake holders implementing projects among communities mainly in developing countries have realised the importance of community and other stakeholder involvement and participation in the entire project life cycle. The stakeholders include local community members, their leaders/representatives and community groups, faith based organisations, local CBOs and religious leaders within the communities (Gaturu \& Muturi, 2014). Others include organisations both local and international already working with the communities and the local business community. The projects will be considered to have performed if they meet the objectives set by the donors and according to the expectations of the local community who are the main beneficiaries. They will also be measured according to how well they will be sustained after the exit of the donors (ALNAP, 2009). Globally, more people live in urban areas than in rural areas, with $54 \%$ of the world population residing in urban areas in2014, (UN, 2014). According to Oxfam (2009), the slums in Nairobi are characterized by congestion, inhuman living conditions in the realms of environment, poverty and health.

Korogocho informal settlement is one of the oldest informal settlements in Nairobi County with a total population of 124,401 people (2016 population projections). Majority of these people live in semi structured houses made of mad and corrugated iron sheets with an earthly floor and with no access to clean water and sanitation facilities. The current study specifically 
examined the performance of a youth empowerment project dubbed, creating jobs and cleaner cities through recycling project, which was a partnership between Youth Initiatives Kenya (YIKE) in Korogocho, and Oxfam Kenya. YIKE is a local organisation that is registered as an NGO by the NGO board and works with youth groups in informal settlements of Nairobi while Oxfam is an international NGO that works with others to alleviate poverty. The project sought to secure the lives of the youth living in Korogocho and Dandora by establishing solid waste management through setting up of a recycling plant and equipping the youth with business and entrepreneurial skills. Lack of an elaborate county government solid waste management program presented the project partners with an ideal opportunity to organize 10 youth groups with a total membership of 1650 members to engage in collecting, storage and recycling of solid waste as an alternative income generating activity. According to YIKE Market Study Report (2013), the project had achieved moderate success which led to the transformation of the lives of the participating youth as well as trickling down of benefits to stakeholders within the community. Despite the visible success of the project there has been limited empirical examination of the contribution of community participation to the success of the project. The current study sought to fill the literature void and offer insights to other similar projects on ways to improve their performance.

\section{STATEMENT OF THE PROBLEM}

The success of projects is a major challenge in many developing countries including Kenya. This has left communities complaining that they do not enjoy the intended benefits from projects that are implemented to improve their lives such as through creating employment opportunities thus alleviating poverty. On the other hand, the donors who provide the funds complain of lack of value for money since most projects do not perform to expectations and objectives as set out by the donors. Unsuccessful and unsustainable projects deny communities the expected benefits from these investments. Participation of communities in projects is one of the factors that have been identified as having an influence on a community-based project. Empirical literature is however divided on the influence of community participation on project success. Some studies show that community participation leads to positive project outcome (Mansuri \& Rao, 2008). Other studies also show that greater community participation is associated with higher project outcomes and better services (Khawaja, 2006). According to Dudley (2005), participation in community projects is connected to power relations and politics within the community, thus, whenever a project tries to promote participation, it has to be ready to confront the political context and its consequences. As a result, the use of participation to drive community development projects can eventually lead to poor performance.

Locally, (Afande, 2013) indicates that unregulated community participation may lead to managerial inefficiencies which may affect the project performance. However, in general the author indicates that community participation can foster project success. Lensinko, (2015) is of the view stakeholder involvement is key to better monitoring and evaluation which enhances the project effectiveness and efficiency. Ngacho (2013) concludes that community participation ensures that only the projects that meet community needs are undertaken and it enhances ownership which stimulates overall project performance. Gaturu and Muturi (2014) concluded that continous monitoring and evaluation of the projects was central to timely completion of project and achievability of the project objectives in Kenya. The above presents and empirical gap that the current research sought to fill this gap. However despite the above literature; there is no congruence in the literature on the influence of commuity participation on performance of donor funded youth projects in Korogocho. More so, the majority of the studies have focussed on government-funded projects and there is scant literature examining donor funded projects in Korogocho area. This study examined the 
effect of community participation on the project performance of donor funded youth projects in Korogocho, Nairobi,County.

\section{GENERAL OBJECTIVES}

The general objective of the study was to examine the influence of community participation on the performance of donor funded youth projects in Korogocho, Nairobi.

Specific objectives were:

i. To establish the effect community participation in project identification phase on the performance of donor funded youth projects in Korogocho, Nairobi.

ii. To determine the effect community participation in project planning phase of the youth project on the performance of donor funded projects in Korogocho, Nairobi.

iii. To examine the effect community participation in project implementation of the youth project on the performance of donor funded projects in Korogocho, Nairobi.

iv. To determine the effect of community participation in monitoring and evaluation of the youth project on the performance of donor funded projects in Korogocho, Nairobi.

\section{THEORETICAL REVIEW}

\subsection{Theory of Social Change}

The theory of change was proposed by Beisser (1970); when applied to social change processes, represents a thinking action alternative to other more rigid planning approaches and logics. The theory of change also describes the types of interventions that bring about results hoped to or expected (Perls, 2005). According to the theory of social change, the abstracts ideologies held by stakeholders could shape the attainment of the future goals of a project. The assumptions held by the community in the monitoring and evaluations could prove to be critical in enhancing the self-capabilities which would be instrumental in enhancing the success of a project. (Rogers, 2008). This theory helps to describe how alterations may occur at different stages of a project without any sure prediction being made. It further highlights how these changes can be altered through strategic intervention measures. This theory is important to the study as it highlights a conscious and clear visualization that enables the project stakeholders to focus on the key aspects that support better project performance. This theory anchored community participation in the project process within donor funded projects in Korogocho slums.

\subsection{Stakeholder Theory}

The stakeholder theory was advanced by Freeman (1994) and holds that the purpose of any business is to enhance the value of the organization and promote value for all the stakeholders. The Stakeholder Theory exhaustively covers the various stakeholders involved in project implementation such as donors, researchers, management and even the ultimate users of the project (Dennis, 2009; Donaldson\& Preston, 2010). This theory holds that the coordination between the various project stakeholders both internal and external can be instrumental in fostering cohesion in the undertaking which will lead to attainment of the mutual goals within such a system of partnership (Miles, 2012). Phillips (2007) also indicates that the involvement of project beneficiaries will foster the economic value of the project through skills development. This will lead to more users' getting involved in the project execution as employees and increase their sense of ownership which is pivotal in attaining the project goals. This theory further added credence to the need for community participation in project management as a key tool of fostering project success. 


\subsection{Resource Based View Theory}

Resource based view theory is traced back to Penrose (1959) who believed that the resources that a firm had, had major implications on how the firm performed. Resource Based View theory is all about the managing the resources well. If a company can improvise, utilize, manage and hold their important resources, they can survive and be a good competitor in the domestic or international market. The major concern in Resource Based View is focused on the ability of the firm to maintain a combination of resources that cannot be imitated easily by other competitors (Ansoff, 1965). According to Downes (2001), the main problems that face the implementation of a project are from within the project execution team or from the external environmental linkages. This theory was instrumental in the current study in examining how the community members (stakeholders) can be a resource to an organization in the execution of a project. The theory guided in assessing how the community member's role as a firm asset impacts the project performance.

\section{CONCEPTUAL FRAMEWORK}

\section{Community participation in Project identification:}

- Selection and prioritization of the projects

- Needs Assessment

\section{Community participation in Project planning:}

- Budgeting and Allocation of funds

- Selecting of implementation team

- Developing work plan

\section{Community participation in Project implementation:}

- Resource allocation

- Resource utilization

- Management of project activities

\section{Project monitoring and evaluation:}

- Review of progress

- Preparing reports and feedback

- Work plan review

\section{Project performance:}

- Timely completion

- Effective and efficient budgetary use

- Sustainability of project

- Meeting project objectives 


\section{Figure 1: Conceptual Framework}

The conceptual framework depicts the interaction between community participation and project performance. The community participation is conceptualized in four main project cycles; the project identification, the project planning, the project implementation and the project monitoring and evaluation. The dependent variable - project performance was measured using timely completion, effective and efficient budgetary use, sustainability of the project and meeting the project objective.

\section{RESEARCH METHODOLOGY}

The current study employed a descriptive research design. The researcher obtained a list of 1650 members from 10 YIKE groups who were involved in the project. The unit of observation was the specific groups with the unit of analysis being the 1650 members in the groups. The study further interviewed 3 project managers, Oxfam Kenya who is the funding partner of the YIKE project and two 2 project officers from YIKE who were the implementing partner. Hence the total target population was 1653 respondents. The study sample was selected from the 10 groups working with YIKE and staff from Oxfam Kenya. The study adopted a random sampling design. This ensured that there is equal representation among all the respondents since they are assumed to have the same knowledge on community participation and the project performance. Primary data was collected using semistructured questionnaires through the drop and pick method. The semi-structured questionnaires consisted of open and closed ended questions. The questionnaire was developed in line with the research objectives using a 5-point Likert scale. The study also utilized a key informant interview schedule for the Oxfam project managers. Secondary data was collected from the project reports, published journals and other open-access publications. The data collected was both quantitative and qualitative data. Quantitative data was analysed using Statistical software (SPSS, v. 23) and the output presented using descriptive statistics namely: mean, standard deviation, percentages proportions. The collected qualitative data was analyzed using content analysis. The study also employed Pearson correlation and inferential statistics that utilized a multiple regression analysis. The statistical significance of the study was measured at 5\% significance level using ANOVA Tests. The results of the analysis were presented charts, tables and bar graphs.

\section{STUDY FINDINGS}

The main objective of the research was to examine the effect of community participation on the performance of donor funded youth projects in Korogocho. The study conducted both correlation and regression analysis to estimate the magnitude and nature of the relationship. The first research objective of the study sought to examine the effect of community participation in project identification on project performance

Table 1: Community Participation in Project Identification on Project Performance

\begin{tabular}{llc}
\hline & & Project Performance \\
\hline Community participation in Identification & Pearson & $.559^{* *}$ \\
& Correlation & .000 \\
& Sig. (2-tailed) & 111 \\
\hline
\end{tabular}

The results of the study showed that community participation in project identification had a positive and significant effect on project performance as indicated by $p$-value $=.559$; Sig value $=.000<.005$. These results are supported by Kerzner, (2017) who concluded that involving the community in selection of the project was key to better project performance. Berssaneti and Carvalho, (2015) also indicated that project selection was key component for 
determining the performance of the project. The second research objective of the study sought to examine the effect of community participation in project planning on project performance

Table 2: Community Participation in Project Planning on Project Performance

\begin{tabular}{llc}
\hline & & Project Performance \\
\hline Community participation in Planning & Pearson & $.435^{* *}$ \\
& Correlation & .000 \\
& Sig. (2-tailed) & 111 \\
\hline
\end{tabular}

The results of the study showed that community participation in project planning had a moderate positive and significant effect on project performance as indicated by $p$-value $=$ .435; Sig value $=.000<.005$. The findings are in agreement with Gwaya, Masu, and Wanyona, (2014) who concluded that involving stakehoders in the planning was a critical factor of ensuring the project success. The third objective of the study sought to examine the effect of community participation in project implementation on project performance

Table 3: Community Participation in Project Implementation on Project Performance

\begin{tabular}{clc}
\hline \multicolumn{1}{c}{} & & Project Performance \\
\hline Community participation in Implementation & Pearson & $.422^{* *}$ \\
& Correlation & .000 \\
& Sig. (2-tailed) & 111 \\
& $\mathrm{~N}$ & \\
\hline
\end{tabular}

The study objective sought to examine the effect of community participation in project implementation on the project performance. The results of the study showed that community participation in project implementation had a moderate positive and significant effect on project performance as indicated by $p$-value $=.422$; Sig value $=.000<.005$. Ananga, Njoh, Anchang, and Akiwumi (2016) also idnicated that involvement of the community in the management and implementation process had a positive influence on the performance of community projects.

The fourth objective of the study sought to examine the effect of community participation in project monitoring and evaluation on project performance

Table 3: Community Participation in Project Monitoring and Evaluation on Project Performance

\begin{tabular}{lccc}
\hline & & & Project Performance \\
\hline Community & participation & in & Monitoring \\
Evaluation & & Coarson & $.391^{* *}$ \\
& & Sig. (2-tailed) & .000 \\
& & $\mathrm{~N}$ & 111 \\
\hline
\end{tabular}

The study objective sought to examine the effect of community participation in project monitoring and evaluation on the project performance. The results of the study showed that community participation in project monitoring and evaluation had a weak positive and significant effect on project performance as indicated by $p$-value $=.391$; Sig value $=$ $.000<.005$. Wanjiru (2013) also concluded that having elaborate monitoring and evauation systems influences the effectiveness of the project positively. Ngacho (2013) also indicated there is a positive effect of community participation on the project performance. 
The general objective of the study sought to examine the effect of community participation on the project performance of donor funded projects. The study conducted a linear regression analysis to estimate the extent of the relationship.

Table 4: Regression Summary

\begin{tabular}{|c|c|c|c|c|}
\hline Model & $\mathrm{R}$ & R Square & Adjusted R Square & $\begin{array}{l}\text { Std. Error of the } \\
\text { Estimate }\end{array}$ \\
\hline 1 & $.600^{\mathrm{a}}$ & .360 & .336 & 4.06308 \\
\hline
\end{tabular}

The above results present the summary results for the linear regression of the association between community participation and project performance. The findings of the analysis indicate that holding other factors constant community participation explains $36 \%$ variations in project performance as indicated by a $R^{2}=.360$. This implies that other factors not considered in the model explain $64 \%$ variations in the project performance. The above results are consistent with Musa (2012) who indicated there is a positive association between community involvement and project performance.

The study further conducted an ANOVA test to examine the statistical significance of the research model being adopted.

Table 5: ANOVA Model

\begin{tabular}{llccccc}
\hline Model & & Sum of Squares & Df & Mean Square & F & Sig. \\
\hline 1 & Regression & 984.051 & 4 & 246.013 & 14.902 & $.000^{\mathrm{b}}$ \\
& Residual & 1749.913 & 106 & 16.509 & & \\
& Total & 2733.964 & 110 & & & \\
\hline
\end{tabular}

a. Dependent Variable: Project Performance

b. Predictors: (Constant), Community Monitoring and Evaluation, Community Planning, Community Identification, Community Implementation

The results above present the ANOVA model which sought to examine the statistical significance of the model in determining the association between the study variables (community participation*project performance). The results indicated that the f-statistic $=$ $14.902, \mathrm{p}$-value $=.000<.005$. This indicates that the model was statistically significant and fit in explaining the effect of community participation on the project performance of donor funded projects.

The research further sought to examine the regression coefficients of the regression equation. The results indicated that;

Table 6: Regression Coefficients

\begin{tabular}{llccccc}
\hline & & \multicolumn{2}{c}{$\begin{array}{l}\text { Unstandardized } \\
\text { Coefficients }\end{array}$} & $\begin{array}{c}\text { Standardized } \\
\text { Coefficients }\end{array}$ & & \\
\hline 1 & $\mathrm{~B}$ & Std. Error & Beta & $\mathrm{t}$ & Sig. \\
\hline & (Constant) & 5.221 & 1.627 & & 3.210 & .002 \\
& $\begin{array}{l}\text { Community } \\
\text { Identification }\end{array}$ & .292 & .077 & .383 & 3.815 & .000 \\
& $\begin{array}{l}\text { Community Planning } \\
\text { Community }\end{array}$ & .095 & .066 & .143 & 1.433 & .155 \\
& $\begin{array}{l}\text { Implementation } \\
\text { Community }\end{array}$ & .071 & .070 & .105 & 1.015 & .313 \\
& Monitoring Evaluation & .093 & .089 & .100 & 1.047 & .298 \\
\hline a. Dependent Variable: Project Performance & & & &
\end{tabular}


The resultant regression equation was; $Y=5.221+.292 X 1+.095 X 2+.071 X 3+.093 X 4$. The regression equation above indicates that; there is a positive and significant effect of community participation on project performance of donor funded projects as indicated by $\beta=.292$, sig $=.000<.005$. This implies that a unit change in the community participation in project identification would result in a .292 change in project performance. Afande (2013) similarly indicated that there was a positive and significant effect of project identification on the project performance in donor-aided projects. The results of the study further show that there is a positive nonsignificant effect of community participation in planning as indicated by a $\beta=.095$, sig $=.155>.005$. A unit change in community participation in planning would result in a .095 change in project performance. Ananga, Njoh, Anchang and Akiwumi (2016) results were consistent with above results findings in their conclusions that community participation in project planning was positively related to project performance.

The findings of the research further indicated that there was a positive nonsignificant effect of community participation in project implementation on the project performance as indicated by $\beta=.071$, sig $=.313>.005$. A unit change in community participation in implementation would result in a .071 change in project performance. Brett, Margaret and Tammo (2007) also concluded that project involvement in implementation was key in enhancing the sustainability and performance of projects. The findings of the research further indicated that there was a positive nonsignificant effect of community participation in project monitoring and evaluation on the project performance as indicated by $\beta=.093$, sig $=.298>.005$. A unit change in community participation in monitoring and evaluation would result in a .093 change in project performance. Lensinko (2015) also indicated that monitoring and evaluation of projects was integral in positively improving project performance.

\section{CONCLUSIONS}

In regard to the community participation in the project identification the study concludes that it is vital to involve the community in selecting the project as this will create a sense of ownership. The study also concludes that involving the community in selecting the location of the project will ensure the security of the project. Further the study concludes that the community involvement in the planning of the project will ensure that vital ideas are shared among the group members which will create an attachment to the project. This will be key to ensuring the sustainability of the project. In regard to community participation in the planning for the project; the study concludes that the community members should be involved in designing the implementation plans. This will ensure that all concerned stakeholders will strive to meet the laid time frames. The study further concludes that the community should be involved in planning for the project goals and priorities. This will ensure all their activities are geared towards meeting the laid down goals.

Concerning the community involvement in the implementation of the project the study concludes that involvement in the day to day management is key to ensuring there is efficient utilization of the resources. The study further concludes that involving the community in making financial decisions will ensure that the resources are optimally shared and accountability can be fostered. Furthermore training the community members on the implementation process will contribute to effectiveness in the project execution. Concerning the community involvement in the monitoring and evaluation the study concludes that their involvement in setting the monitoring and evaluation plan will ensure that the feedback recommendations are adopted to ensure better project performance. Further conducting regular group meetings will ensure that the stakeholders have adequate knowledge on the project deliverables and measurement of the attainment of the goals. This will enhance their capacity which is key to the long-term sustainability of the project. 


\section{RECOMMENDATIONS}

The research recommends that the donor agencies should conduct more capacity building and mentorship workshops that will enhance the capacity of the youth groups to manage the programs independently in the long term. The study further recommends that the donor agencies should involve government officials in the selection of projects within the community. This will ensure that the selected projects can be aligned to the government policy initiatives. This will foster the attainment of project goals. The study further recommends that the donor agencies should support the youth groups in attending benchmarking trips among other youth groups in different counties to foster their planning capabilities. This will ensure that in designing the projects the youth groups are not overambitious and the going concern of the project is assured from the initiation stage. The study further recommends that the youth groups should strive to seek expert opinions and involvement before undertaking project execution. This will ensure that due analysis is conducted before embarking on the project to ensure any caveats are avoided in the course of the project. In regard to the monitoring and evaluation of the project the study recommends that competent external agencies should be tasked with conducting the M\&E activities. This will ensure an impartial report is generated. Further the groups should seek expert training on the project cycle so that in the future they can leverage on the monitoring and evaluation reports to ensure effective project implementation.

\section{REFERENCES}

Afande, O. F. (2013). Factors Affecting use of Donor Aid by International NonGovernmental Organizations in Kenya: A case of USAID. . International Journal of Business Management and Administration, , 2(5), 089-116.

Ali, S. (2013). Participatory Governance Reform: A Good Strategy for Increasing Government Responsiveness and Improving Public Services. World Development, , Vol. 40 No. 12.

ALNAP. (2009). Participation handbook for humanitarian field workers - Involving crisis: Affected people in a humanitarian response. www.urd.org/Participation-Handbook.

Ananga, E. O., Njoh, A. J., Anchang, J. Y., \& Akiwumi, F. A. (2016). Participation-related factors influencing performance in four urban-based community-operated water schemes in Kisumu, Kenya. . Community Development Journal, , 52(2), 319-336.

Ansoff, H. I. (1965). Corporate Strategy: Business Policy for Growth and Expansion. McGraw-Hill Book.

Barasa, F., \& Jelagat, T. (2013). Community Participation in Project Planning,Management and Implementation: Building the Foundation for Sustainable Development. International Journal of Current Research, Vol. 5, Issue, 02, pp.398-401.

Beisser, A. (1970). The paradoxical theory of change. . Gestalt therapy now, , 77-80.

Berssaneti, F. T., \& Carvalho, M. M. (2015). Identification of variables that impact project success in Brazilian companies. International Journal of Project Management, , 33(3), 638-649.

Brett, G., Margaret, P., \& Tammo, L. (2007). Analysis of Community Participation in Projects Managed by Non-Governmental Organizations A Case of World Vision in Mali. World Vision Studies.

Chess, C., \& Purcell, K. (2009). Youth participation and the environmental community projects: Do we know what works? . Environmental Science and Technology , 33 (16), 2685-2692.

Chikati, J. (2009). Participatory Project Identification and Planning, A Regional Partnership for Resource Development. IFDM Gardens off Ngong Road Nairobi: Signal Press Ltd, . 
Cleaver, P. (2006). Is Increasing Community Participation Always a Good Thing? Journal of the European Economic Association.

Downes, L. (2001). Strategy Can Be Deadly - Industry Trend or Event ${ }^{\mathrm{ee}}$. The Industry Standard.

Dudley, E. (2005). The critical villager: Beyond community participation. . London \& New York: : Routledge.

Freeman, R. E. (1994). The politics of stakeholder theory: Some future directions. . Business ethics quarterly, , 409-421.

Gaturu, N. S., \& Muturi, W. (2014). Factors affecting the timeliness of completion of donorfunded projects in Kenya: a case of world agro forestry centre (ICRAF). European Journal of Business Management, , 2(1), 189-202.

Gaturu, N., \& Muturi, W. (2014). Factors affecting the timeliness of completion of donorfunded projects in Kenya: a case of world agro forestry centre (ICRAF). . European Journal of Business Management, , 2(1), 189-202.

Gwaya, A. O., Masu, S. M., \& Wanyona, G. (2014). A Critical Analysis of the Causes of Project Management Failures in Kenya. . Blue Eyes Intelligence Engineering \& Sciences Publication Pvt Ltd.

Ika, L. A., Diallo, A., \& Thuillier, D. (2012). Critical success factors for World Bank projects: An empirical investigation. . International Journal of Project Management, , 30(1), 105-116.

Kerzner, H. (2017). Project management metrics, KPIs, and dashboards: a guide to measuring and monitoring project performance. John Wiley \& Sons.

Khwaja, A. I. (2006). Is increasing community Participation always a good Thing? . Journal of the European Economic Association, April-May 2006 2(2-3):427- 436.

Kumar, S. (2009). Methods for Community Participation: A Complete Guide for Practitioners, . Vistar Publications, , New Delhi India p. 23.

Lemma, T. (2014). The role of project planning on project performance in Ethiopia. $A$ Dissertation of MA Thesis.

Lensinko, N. (2015). Factors influencing performance of monitoring and evaluation of government projects in Kenya: a case of constituency development fund projects in Narok east sub-county. University of Nairobi.

Makori, J. O., \& Wanyoike, D. (2015). Assessment of result based monitoring and evaluation on performance of donor funded value chain projects in Kenya. JKUAT,PhD Thesis.

Management Sciences for Health. (2012). Global and Donor Financing. . MDS-3 Managing Access to Medicines and Health Technologies,

Mansuri, G., \& Rao, V. (2004). Community based and Driven Development: A critical Review.". The World Bank Research Observer, , 19(1): 6, 31.

Mathew, M. (2011). Review of BPO. . Journal of management, , 3, 26-3.

Mugenda, M., \& Mugenda, G. A. (2003). Research Methods: Qualitative and Quantitative Approach. Nairobi: : Laba Graphics Services.

Mulwa, F. (2008). Participatory Monitoring and Evaluation of Community projects. Nairobi, Kenya: Paulines Publications Africa, .

Musa, S. (2012). Feeder Roads and Food Security in Balancing the Load: Women, Genderand Transport. . UK: Zed Books Ltd., , Pp. 79-94.

Ngacho, C. (2013). An Assessment of the Performance of Public Sector Construction Projects: An Empirical Study of Projects Funded Under Constituency Development Fund (CDF) in Western Province, Kenya. Unpublished PhD thesis, Delhi: University of Delhi. 
Nikkhah, H. A., \& Redzuan, M. (2009). Participation as a Medium of Empowerment in Community Development. European Journal of Social Sciences , Volume 11, Number 1 (2009).

Okafor, C. (2005). Community Driven Development: Concepts and Procedure. . New Bussa: LEEMP workshop.

Penrose, E. (1959). The Theory of the Growth of the Firm, . New York: Wiley.

Rondinelli, D. A. (2013). Development projects as policy experiments: An adaptive approach to development administration. Routledge.

Shrimpton, R. (2009). Community participation, growth monitoring, and malnutrition in the third world," . Human Ecology Forum, , Vol. 17.

World Bank . (2008). Localizing Development: Does Participation Work?,. Washington DC: World Bank Policy Research Report, World Bank, .

YIKE. (2013). Improving markets for the Poor. Baseline Report. Youth Initiative Kenya.

This is an open-access article published and distributed under the terms and conditions of the $(\mathrm{cc}) \mathrm{EY}$ Creative Commons Attribution 4.0 International License of United States unless otherwise stated. Access, citation and distribution of this article is allowed with full recognition of the authors and the source.

Authors seeking to publish with an International Peer Reviewed Journal should consider www.ijcab.org by writing to the Editor at editor@ijcab.org. The articles must be quality, value adding and meet originality test. 